\title{
Peningaktan Kualitas dan Produktifitas Sambal Kerang dengan Mesin Pelumat dan penggoreng Mekanik di Sentra Ikan Bulak Surabaya
}

\author{
Nurul Widji Triana \\ Universitas Pembangunan Nasional \\ "Veteran" Jawa Timur
}

\author{
Suprihatin \\ Universitas Pembangunan Nasional \\ "Veteran" Jawa Timur
}

\author{
Lilik Suprianti \\ Universitas Pembangunan Nasional \\ "Veteran" Jawa Timur
}

\begin{abstract}
Oyster is a marine product which found abundantly in Kenjeran shore, Surabaya. They usually are sold directly in the market as a fresh oyster. But the Small size and low-quality oysters were not sold in the market. To improve small oysters' value, they need to be processed to be oyster chili and oyster floss. UKM Bunda is a group that running a business on fish and oyster processing. Located in Bulak district, Surabaya city. Oyster chili and oyster floss from UKM Bunda are attracted many tourists, but their production is still under market demand. This is because they produce oyster chili and floss manually, so it takes time, and the product quality are changeable. This public service project improves the oyster chili quality by applying the proper technology from UPN "Veteran" Jawa Timur. They are the blending machine (patent registration A00201204059) and mechanic machine frying (patent certified IDD-00000938). By using blending machine and mechanic frying can decrease time production and increase the production capacity. We also educate people to improve their capacity in business management and marketing. This public service's impact is, increase in production capacity from $5 \mathrm{~kg}$ per week becomes $25 \mathrm{~kg}$ per week, moreover, their product can be more hygiene and better quality.
\end{abstract}

Keywords: oyster chili, grinding machines, heater mixing, UKM Bunda

\begin{abstract}
Abstrak
Kerang merupakan salah satu hasil laut yang banyak terdapat di perairan Kenjeran, Surabaya. Kerang- kerang yang berukuran kecil dan kualitas rendah kurang laku di pasaran. Sehingga untuk meningkatkan nilai tambah, kerang kerang kecil tersebut diolah menjadi produk makanan seperti sambal kerang dan abon kerang. UKM Bunda adalah kelompok usaha bersama yang bergerak di bidang pengolahan teripang dan kerang yang berlokasi di sentra pengolahan hasil laut kelurahan kedung cowek, kecamatan Bulak Surabaya. Walaupun banyak diminati wisatawan, namun produk olahan kerang dari UKM Bunda belum dapat memenuhi permintaan pasar karena proses produksi yang masih dilakukan secara konvensional. Peralatan yang dipakai masih sederhana sehingga proses produksi memerlukan waktu yang lama serta produk yang kurang terjaga kualitasnya. Pada kegiatan pengabdian masyarakat ini dilakukan mekanisasi dalam proses pembuatan sambal kerang dan abon kerang dengan mengaplikasikan hasil teknologi Tepat Guna (TTG) dari UPN Veteran Jawa timur berupa mesin pelumat(telah terdaftar di HaKI desain industri A-00201204059), dan mesin penggoreng mekanik (tersertifikasi HaKI IDD-00000938) dengan mitra UKM Bunda. Peningkatan kualitas Sumber Daya Manusia dan penguatan kelembagaan juga dilakukan untuk memberikan wawasan kepada pelaku UKM terhadap bisnis dan pemasaran. Dampak yang dirasakan dari kegiatan pengabdian masyarakat ini adalah adanya peningkatan produksi sambal kerang dari $5 \mathrm{~kg} / \mathrm{minggu}$ menjadi $25 \mathrm{~kg} / \mathrm{minggu}$. Proses produksi lebih higienis serta kualitas semakin terjaga.
\end{abstract}

Kata kunci: sambal kerang; mesin pelumat; mesin penggoreng, UKM Bunda

\section{Pendahuluan}

Penunjang perekonomian terbesar bagi masyarakat di sekitar pantai Kenjeran adalah hasil laut. Pemerintah Kota Surabaya memfasilitasi dengan mendirikan sarana untuk jual beli hasil laut dan produk produk olahan hasil laut bernama Sentra Ikan Bulak yang terletak di kelurahan Kedung 
Cowek kecamatan Bulak Surabaya. Komoditas yang diperdagangkan di sentra ikan bulak antara lain, ikan segar, udang, kerang, aneka olahan ikan, ikan asin, dan kerupuk. Selain sebagai sentra perdagangan, sentra Ikan Bulak juga menjadi tujuan wisata bagi pengunjung pantai Kenjeran. Lokasi Sentra Ikan Bula sangat strategis yaitu dekat dengan kawasan wisata pantai Kenjeran dan akses menuju jembatan Suramadu. Hal ini menjadikan Sentra Ikan Bulak ramai pengunjung. Setiap harinya, terutama pada hari libur. Penampakan Sentra Ikan Bulak dari depan terlihat pada gambar 1

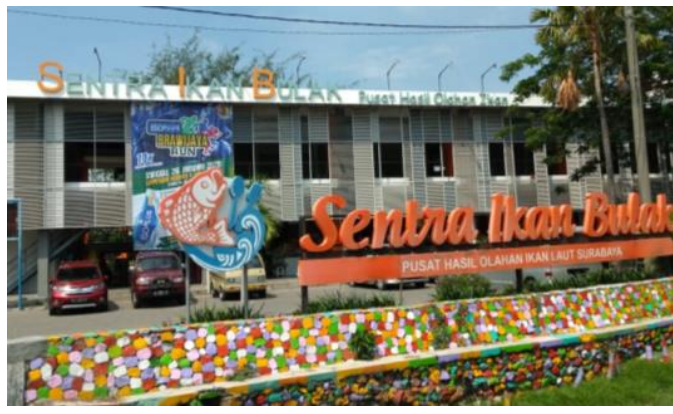

Gambar 1. Sentra Ikan Bulak Kedung Cowek Surabaya

Salah satu hasil laut yang menjadi komoditas perdagangan di sentra ikan Bulak adalah kerang. Kerang banyak diminati oleh masyarakat. erang juga memili kandungan nutrisi yang cukup tinggi. Kandungan nutrisi dari beberapa jenis kerang kerang dapat dilihat di tabel berikut ini

Tabel 1 kandungan gizi kerang (Astrid A. Tari, 2018)

\begin{tabular}{lccccc}
\hline \multirow{2}{*}{ Jenis kerang } & \multicolumn{5}{c}{ Kandungan } \\
\cline { 2 - 6 } & Kadar air & Abu & Protein & Lemak & Karbohidrat \\
\hline $\begin{array}{l}\text { Anadara } \\
\begin{array}{l}\text { Uropygmelana } \\
\text { Codakia }\end{array}\end{array}$ & 81,51 & 3,74 & 10,87 & 0,83 & 16,43 \\
$\begin{array}{l}\text { Puncatata } \\
\text { Telina }\end{array}$ & 88,05 & 3,17 & 6,46 & 0,56 & 14,5 \\
$\begin{array}{l}\text { Radiate } \\
\begin{array}{l}\text { Sunetta } \\
\text { Trunccata }\end{array}\end{array}$ & 87,35 & 3,03 & 6,84 & 0,54 & 16,32 \\
$\begin{array}{l}\text { Trachycardium } \\
\text { Subrogum }\end{array}$ & 89,91 & 4,44 & 10,24 & 2,17 & 16,29 \\
\hline
\end{tabular}

Walaupun banyak diminati masyarakat, namun tidak semua kerang mudah laku di pasaran. Kerang yang berukuran kecil dan kualitasnya kurang bagus tidak diminati oleh konsumen. Hal ini mendorong sekelompok masyarakat yang tergabung dalam Kelompok Usaha Kecil dan Menengah (UKM) "Bunda" mengolah kerang kerang yang kurang laku di pasaran menjadi berbagai produk olahan kerang, seperti nugget, risoles, siomay, martabak, sambal kerang dan abon kerang untuk meningkatkan nilai ekonomis dari kerang yang tidak laku. Pada tahun 2017 melalui program pengabdian masyarakat, Sulestiane dkk telah memberikan perhatian kepada UKM Bunda untuk produksi makanan olahan kerang dengan memberikan bantuan berupa alat pengaduk sederhana, mixer. Pengaduk serba guna tersebut diaplikasikan untuk pembuatan siomay, risoles, dan nugget kerang. (Sulestiani, Baroroh, Ekowanti, \& Budiman, 2017).

Produk olahan kerang lain yang dikembangkan oleh UKM Bunda adalah sambal kerang. Sambal kerang produksi UKM Bunda banyak diminati oleh wisatawan. Bahkan produk ini menjadi produk unggulan di kawasan Sentra Ikan Bulak. Namun UKM Bunda belum mampu memenuhi permintaan pasar karena proses produksi masih dilakukan dengan cara konvensional. Alat alat 
yang digunakan masih manual dan sederhana. Untuk membuat sambal kerang maka pelumat atau penghalus kerang dan penggorengan menjadi alat utama yang dibutuhkan. Sebelumnya, proses produksi menggunakan gilingan manual untuk menghaluskan kerang. Proses Penggorengan menggunakan wajan biasa sehingga kapasitasnya terbatas. Pengadukan juga menggunakan pengaduk manual sehingga produk kurang merata. Dalam 1 minggu UKM Bunda hanya dapat memproduksi $5 \mathrm{~kg}$ sambal kerang. Sehingga untuk meningkatkan kualitas serta produktifitas diperlukan upaya mekanisasi dengan mengubah proses yang masih manual menjadi proses dengan bantuan mesin. Melalui program Pengabdian Masyarakat Hasil Riset bagi Masyarakat (RISMA), Universitas Pembangunan Nasional "veteran" Jawa Timur, penulis terjun ke lapangan untuk membantu permasalahan yang dihadapi oleh UKM Bunda.

\section{Metode Pelaksanaan}

Dalam pelaksanaan pengabdian masyarakat ini diawali dengan melakukan survey ke lokasi Sentra Ikan Bulak. Survey ini dilakukan dengan melakuakan observasi dan dialog dengan anggota UKM Bunda terkait kendala dan permasalahan yang dihadapi dalam memproduksi sambal kerang dan abon kerang. Dari hasil survey dapat di identifikasi permasalahnya yaitu:

1. Proses produksi sambal kerang dan abon kerang masih mengunakan cara tradisional dan belum ada sentuhan teknologi

2. Teknologi penggorengan masih dilakukan dengan manual sehingga mutu hasil olahan tidak seragam.

3. Terbatasnya Teknologi untuk mendapatkan pola pengemasan produk olahan yang hygienis dan menarik pasar.

\section{Solusi yang ditawarkan}

Untuk mengatasi permasalahan mitra maka langkah langkah yang dilakukan dalam pengabdian masyarakat ini adalah:

1. Melakukan pendekatan dengan Mitra UKM BUNDA untuk memberikan wawasan tentang proses produksi makanan.

2. Memberikan sosialisasi kepada mitra tentang Penerapan Teknologi Tepat Guna(TTG) berupa mesin pelumat atau pemasta kontinyu dan mesin penggoreng mekanik yang merupakan karya dari UPN Veteran Jawa Timur

3. Melakukan demonstrasi TTG mesin pelumat dan penggoreng mekanik untuk mekanisasi Pengolahan Kerang

4. Melakukan uji mesin dan penyempurnaan mesin

5. Melakukan pengawasan dan evaluasi terhadap program.

\section{Hasil dan Pembahasan}

Implementasi dari kegiatan pengabdian masyarakat ini berlangsung selama 8 bulan. Dari metode yang telah kami paparkan, langkah awal untuk memberikan solusi atas permasalahan yang dihadapi mitra adalah dengan melakukan pendekatan kepada UKM BUNDA. Pendekatan ini bertujuan untuk memberikan wawasan tentang proses produksi makanan, seperti standard yang harus dipenuhi. Sesuai dengan peraturan Kepala Badan Pengawas Obat dan Makanan (BPOM), bahwa dalam indutri Rumah tangga harus mengikuti Cara Produksi Pangan Yang Baik Untuk Industri Rumah Tangga (CPPB-IRT). Tujuannya adalah untuk menghasilkan produk makanan yang aman dan layak dikonsumsi (BPOM, 2012).

Selain wawasan terkait Cara produksi Pangan Yang Baik, juga di sosialisasikan upaya peningkatan produksi dengan mengaplikasikan Teknologi Tepat Guna (TTG). Untuk proses pembuatan sambal kerang ada dua alat yang dibantukan kepada mitra yaitu mesin pelumat dan 
mesin penggoreng mekanik. Mesin pelumat yang digunakan adalah mesin pelumat atau pemasta kontinyu. Mesin pemasta kontinyu karya UPN Veteran Jawa Timur dan telah terdaftar di HaKI desain industri A-00201204059. Dengan mesin pelumat membuat prose spenggilingan daging kerang lebih cepat, hasil daging kerang lebih halus dan bumbu lebih merata. Pada gambar 3.1 menunjukkan foto demonstrasi alat pelumat daging kerang. Pada proses pelumatan daging kerang dapat digiling bersamaan dengan bumbunya. Pengabdian masyarakat yang dilakukan oleh wardhanidkk (2017) kepada UKM Winafood, bahwa produksi sambal dengan menggunakan alat penggilingan dapat menurunkan waktu produksi 8-9 jam sampaimenjadi 6-7 jam. (Wardhani, Aryanti, Buchori, \& Cahyono, 2018)

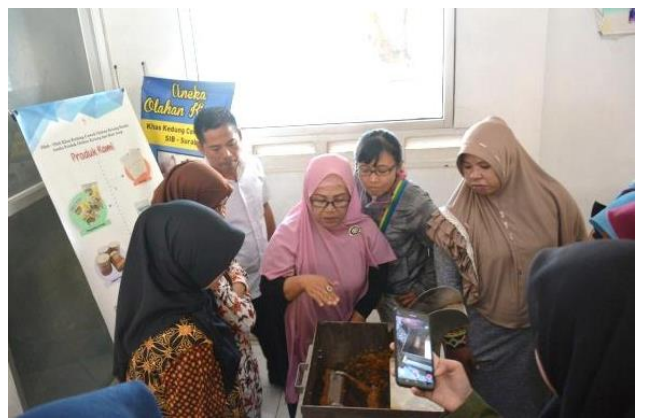

Gambar 2. Uji coba mesin pelumat kerang

\section{Mesin Penggoreng Mekanik}

Mesin penggoreng mekanik yang disediakan adalah penggorengan mekanik dengan teknologi heating mixer. Dimana proses penggorengan yang dilengkapi dengan pengaduk. Mesin ini adalah pengembangan dari hasil penelitian Mulyadi dan Triana pada tahun 2014 dan telah tersertifikasi HaKI (IDD-00000938) dalam wujud peralatan TTG. Desain penggoreng mekanik dapat dilihat dari gambar berikut

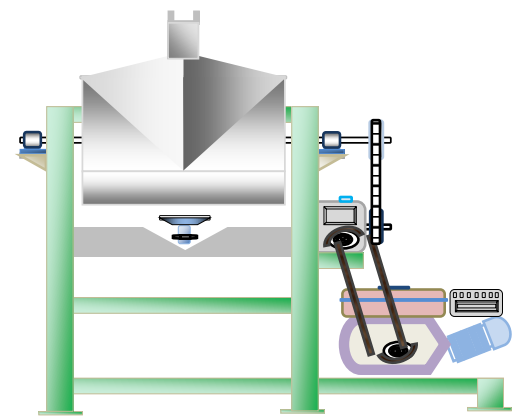

Gambar 3. Desain mesin penggoreng mekanik

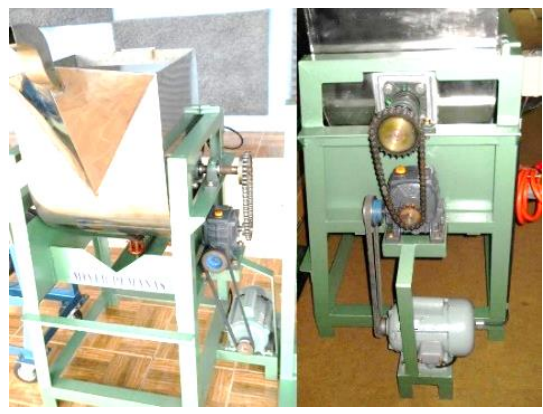

Gambar 4. Penggoreng mekanik (a) tampakdepan, (b) tampakbelakang 
Mesin penggoreng mekanik menggunakan proses batch dengan kapasitas $5 \mathrm{~kg}$ sekali proses. Waktu penggorengan berlangsung sekitar $1 \mathrm{jam}$. Bahan bakar mesin penggoreng mekanik menggunakan gas LPG. Pada mesin penggorengan sudah dilengkapi dengan alat pengaduk, sehingga tidak perlu diaduk secara manual. Proses pencampuran dan pematangan juga lebih merata. Mesin penggoreng mekanik ini dapat digunakan untuk produksi sambal kerang maupun abon kerang. Mesin penggoreng mekanik dapat digunakan tanpa menggunakan minyak.

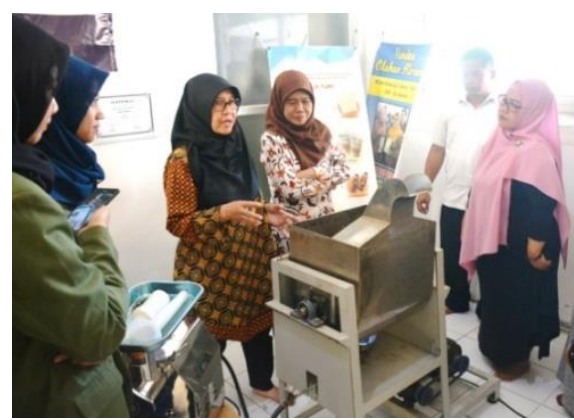

Gambar 5 Uji coba mesin peggoreng mekanik

Setelah proses penggorengan maka proses yang tak kalah penting adalah pengemasan. Sambal kerang produksi UKM Bunda tidak menggunakan bahan pengawet sehingga proses pengemasan perlu diperhatikan untuk menjaga sambal agar tahan lama. Faktor penting yang harus diperhatikan dalam proses pengemasan adalah keasaman $(\mathrm{pH})$, dan temperature pasteurisasi. (Nursari, 2016). Untuk pengemasan menggunakan botol plastic yang food grade karena ringan, hemat biaya dan aman untuk menyimpan sambal. Sedangkan untuk abon kerang dikemas dengan dua jenis kemasan, bagian dalam menggunakan plastic dan bagian luar menggunakan kertas. Kemasan plastik dimaksudkan karena murah

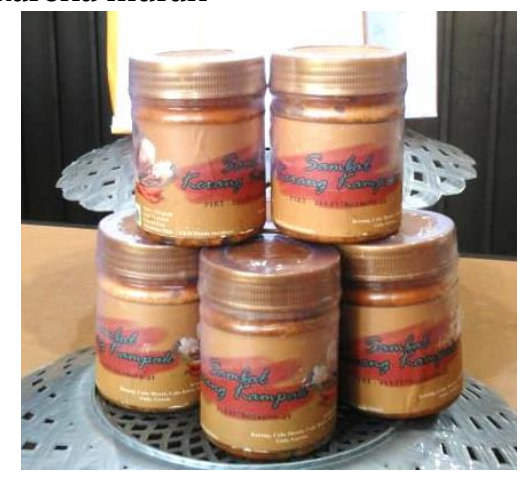

Gambar 6 Produk Sambal kerang UKM Bunda

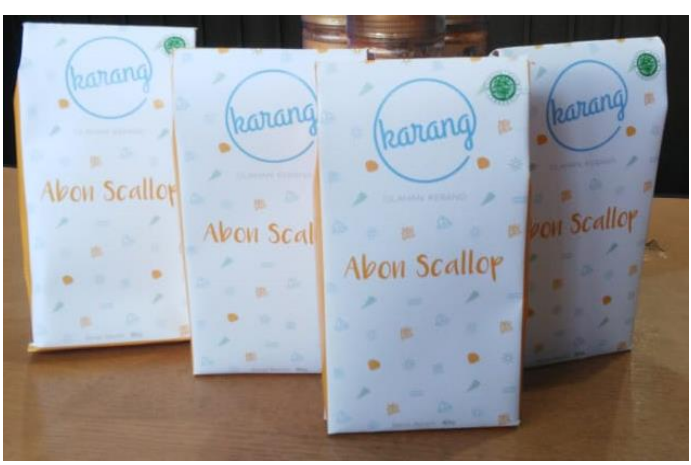

Gambar 7 Produk abon kerang UKM Bunda 


\title{
5. Kesimpulan
}

Setelah dilakukan kegiatan pengabdian masyarakat ini, maka dapat disimpulkan bahwa:

1. Mekanisasi dalam produksi olahan kerang dapat meningkatkan kapasitas dan kualitas produksi sambal kerang

2. Semakin meningkatnya mutu produk semakin naik omset penjualan sambal kerang sehingga meningkatkan perekonomian masyarakat sekitar pantai

3. Mitra semakin termotivasi untuk mengembangkan usahanya menjadi lebih besar

\section{UcapanTerima Kasih}

Ucapan terima kasih kepada Lembaga Penelitian dan Pengabdian Masyarakat (LPPM) Universitas Pembangunan Nasional "Veteran” Jawa Timur untuk pendanaan melalui skim RISMA tahun 2019. Himpunan Mahasiswa Teknik Kimia atas partisipasinya dalam kegiatan pengabdian masyarakat ini

\section{Daftar Pustaka}

Astrid A. Tari, F. K. D., Djeffry Amalo. (2018). Analisis Kandungan Gizi Jenis-Jenis Kerang yang Biasa Dikonsumsi Masyarakat Nembe Desa Oeseli Kecamatan Rote Barat Daya Kabupaten Rote Ndao NTT. Jurnal Biotropikal Sains, 15(2), 1-9.

BPOM, R. (2012). Peraturan Kepala Badan Pengawas Obat dan Makanan (BPOM) Republik Indonesia Nomor HK. 03.1. 23.04. 12.2206 tentang Cara Produksi Pangan yang Baik (CPPB) untuk IRTP: Jakarta.

Nursari, N. (2016). Pengaruh pH dan Suhu Pasteurisasi terhadap Karakteristik Kimia, Organoleptik Dan Daya Simpan Sambal. Jurnal Sains dan Teknologi Pangan, 1(2).

Sulestiani, A., Baroroh, I., Ekowanti, M. R. L., \& Budiman, K. (2017). Penguatan Teknologi Pengolahan Kerang di Kedung Cowek, Kecamatan Bulak Surabaya. Agritrop: Jurnal IlmuIlmu Pertanian (Journal of Agricultural Science), 15(1).

Wardhani, D. H., Aryanti, N., Buchori, L., \& Cahyono, H. (2018). Peningkatan Efisiensi pada Produksi Sambal melalui Scale-up alat Penggiling Bahan Baku. Abdimas unwahas, 2(2).

\author{
Afiliasi: \\ Nurul Widji Triana, Suprihatin, Lilik Suprianti(*) \\ Universitas Pembangunan Nasional "Veteran” Jawa Timur \\ Jl. Raya Rungkut Madya, Gunung Anyar, Surabaya \\ E-mail : nurulwidjitriana@gmail.com, suprihatin.tk@upnjatim.ac.id \\ liliksuprianti.tk@upn.ac.id(")
}

JPP IPTEK (JurnalPengabdian dan Penerapan IPTEK)

https://ejurnal.itats.ac.id/jpp-iptek dipublikasikan oleh LPPM InstitutTeknologi Adhi Tama Surabaya November 2020, Volume 4, Nomor2

Dikirim: 13/01/2020

doi: 10.31284/j.jpp-iptek.2020.v4i2.858

Diterima: $16 / 11 / 2020$ 